\title{
Higher Education Research in Europe
}

\author{
Ulrich Teichler
}

\section{Introduction}

Efforts in the past of analysing the situation of higher education research often have come to similar conclusions. On the one hand, they noted that certain characteristics tended to be named, which in principle apply everywhere where higher education research has emerged. On the other hand, they consistently underscored striking differences that exist between countries (cf. the overviews in Altbach 2002; Teichler 2013c, 2014a).

As regards common characteristics, first, we hear, even in countries with relatively impressive activities in this area, that higher education research is a small field of research. In looking at the overall size of higher education systems worldwide, the important role higher education systems are assumed to play in society, and the range and magnitude of problems which higher education has to cope with, we have to conclude that systematic knowledge on higher education is not held in high esteem even today. Interestingly enough, hardly any figures are presented in the respective overviews: even most of those who know the scene well do not dare to estimate whether there are about 5000 higher education researchers, about 10,000 or even more all over the world. Altbach (2014) recently estimated that there at least 6000 higher education researchers worldwide and even more than 12,000 , if "institutional researchers" were included. Similarly we might ask: are there 2000 or somewhat more or substantially more higher education researchers in Europe?

This caution of estimating the size of the field can be explained in part by a second characteristic. Many scholars undertaking - occasionally or frequentlyresearch in this domain do not consider themselves to be higher education researchers. Many of them understand themselves primarily as representatives of a

U. Teichler $(\bowtie)$

International Centre for Higher Education Research, University of Kassel, Kassel, Germany

e-mail: teichler@incher.uni-kassel.de

(C) The Author(s) 2015

A. Curaj et al. (eds.), The European Higher Education Area,

DOI 10.1007/978-3-319-20877-0_50 
discipline: education, psychology, sociology political science, economics and business studies, law, history, etc.; higher education is just a thematic area for them, but not the core element of their academic identity. Moreover, some scholars, who see their research area as being thematically defined, consider higher education as important, but not as the prime thematic definition; for example, those analyzing research at universities might view themselves as science researchers, and those addressing graduate employment and work might name themselves labour market researchers.

Third, higher education is a field of expertise with very fuzzy borderlines between research on the one hand, and on the other consultancy, administrative oversight, evaluation and other search for evidence. Correspondingly, there is not always a clear distinction as regards who is primarily a researcher or primarily a consultant, evaluator, administrator or "reflective" policy maker or practitioner. For example, various academic journals, edited books, etc., on higher education provide a platform both for scholars and other experts.

Fourth, higher education research is predominantly national in focus or concentrates on smaller units within countries, i.e. regions, individual institutions of higher education or their sub-units, whereby often a strong impact of the national setting on these regional and institutional cases is taken for granted. Higher education research with a world-wide focus or international comparative research on higher education is by no means frequent. For example, a recent survey even of internationally visible journals comes to the conclusion that only $11 \%$ of the articles published in 1992-2011 explicitly compared higher education in at least two countries (Kosmützky and Krücken 2014).

Fifth, though being altogether relatively small, higher education research can be understood as a heterogeneous field. The individual scholars and other experts, each, as a rule, cover only a segment: for example, teaching and learning, as well as staff and students, the higher education system and its societal framework, or governance and administration of higher education. As the system knowledge, as well as the theories and methods are different between such segments, one cannot be surprised to note that a common theoretical framework, a comprehensive information base and overarching network of communication are called for in vain.

Such generalisations about the characteristics of this field, however, have to be viewed with caution, because higher education research varies substantially across countries. There are enormous differences in the size of this field: In some countries, higher education research is a relatively strong field with a visible institutional basis (for example in the United States of America and in China); in other countries, we observe a widely scattered picture of institutions, persons and themes; in other countries, finally, higher education research is marginal or non-existing. Disciplinary affiliations vary across countries. As will be discussed below, there is no country in Europe with a visibility and clear institutional basis of higher education research in the way it holds true for the U.S. Views might vary, whether one would be inclined to name higher education research as sizeable and noteworthy in only two or about half a dozen European countries, or one would name larger numbers of countries in Europe where higher education research is marginal or 
even non-existing. While "higher education" might be the denomination of professor positions and of research units, and possibly teaching in some countries, it is merely a theme among others which individual scholars might address in other countries. Finally, links between research, policy and practice vary: In some countries, higher education policy and governance tend to strive for systematic information as "evidence", while in other countries systematic information remains occasionistic.

\section{Stages of Development of Higher Education Research}

A first worldwide account of higher education research was published in the early 1970s by scholars of the Max Planck Institute for Educational Research, Berlin (Nitsch and Weller 1970-1973). This study showed that it had been a marginal field of research in most countries of the world up to the 1960s. Possibly, the U.S. could be named at that time as the only country where research in this domain was sizeable and visible.

Higher education research began to grow in the 1960s and 1970s, notably in response to two phenomena: the rapid growth of student numbers in many countries and the student protests in select economically advanced countries. Both triggered the notion that the traditional characteristics of the university might not fit anymore, when study ceases to be a privilege for the few and when higher education is increasingly viewed as highly relevant for the technology, economy, society and culture in general.

Scholars of various disciplines got interested at that time in analysing higher education issues. International organisations - notably OECD-undertook systematic analyses, arranged expert committees and stimulated research projects. Centres for 'teaching and learning' or 'staff development' (also 'Hochschuldidaktik', 'onderzoek van onderwijs', etc.) were established at various higher education institutions in many European countries - often with both research and service functions. Countries such as Sweden inaugurated a national programme for the promotion of research projects on issues of higher education, while others established major centres of higher education research outside universities. For example, the nowadays well known institutes in Europe in this domain were founded during this period: The Center for Higher Education Policy Studies of the Twente University (CHEPS) in the Netherlands was founded in 1984, and the International Centre for Higher Education Research of the University of Kassel (INCHER-Kassel) in Germany in 1978. Actually, however, systematic studies on the state of higher education remained scarce during that period as compared to the current situation.

From the late 1980s to the first years of the 21st century, higher education research became a noticeable field of research in many economically advanced as well as in some other countries, as various publications on the state of higher education research show. Many factors seemed to be in play: a growing emphasis 
on evaluation of various kinds, 'accountability' and 'evidence-based policy, a decentralisation of power in higher education and thus an increase of key strategic actors, a professionalization of higher education management, a growing notion of complexity, a loss of confidence in first-hand knowledge on higher education in the wake of internationalisation and globalisation, etc.

Since about that time, a substantial number of accounts on the situation of higher education research have been published. Encyclopaedias on higher education as well explicitly address the state of higher education research (notably Clark and Neave 1992; see also Forest and Altbach 2006; Tight et al. 2009). Some books comprised analyses of the worldwide situation of higher education research, thematically and institutionally (e.g. Sadlak and Altbach 1997; Teichler and Sadlak 2000). Others focussed on the institutional basis of higher education research (Altbach et al. 2007; Altbach and Engberg 2000; Rumbley et al. 2014; Schwarz and Teichler 2000). Again, others addressed the thematic state of higher education and major findings - for example with the help of bibliographic analyses (see for example the books on 'researching higher education' by Tight 2003, 2012). Some overviews focused especially on higher education research in Europe (Frackmann and Maassen 1992; Neave and Teichler 1989; Sursock and Smidt 2010; Teichler 2005). Some membership organisations of higher education researchers or also of other experts show the situation of higher education research as experienced through the activities of these organisations (see Begg 2003; Kehm and Musselin 2013). Some publications comprise essays, partly written by higher education researchers and partly by administrators, policy makers and practitioners in that field (e.g. Fromment et al. 2006; Gaebel et al. 2008). Finally, there is a magnitude of books on specific thematic areas in which the authors and editors, while focussing on key issues of higher education, implicitly provide a valuable overview on the state of higher education research as regards these issues (see for example recently King et al. 2013; Kwiek 2013; Shin and Teichler 2014; Zgaga 2013).

\section{Higher Education Research in Europe and Its Visibility in the English Language}

Higher education research has gained momentum over the years in some European countries. Most of the research in this area is only accessible in the language of the respective country. Yet, publications in the English language often indicate the themes, major results and the expertise available in the various European countries. International and European publications, conferences and expert collaboration in the framework of intergovernmental organisations in the 1960s and 1970s suggest that various scholars from the United Kingdom, Ireland, some Nordic countries, the Netherlands, Germany and a few other European countries had already been active in this field, and that notable research on teaching and learning, curricula etc. had been established in Eastern European countries. Over the years, scholars from 
additional countries became international known, but undoubtedly the communities of researchers in this field continued to differ substantially in size and collaborative activity by country.

The United Kingdom was the first country in Europe where higher education research became a sizeable field. The Society for Research into Higher Education (SRHE), which is based in the UK, was already founded in 1965. It continues to be up to the present the largest community of higher education researchers primarily based in a single European country. SRHE, however, always reached across national borders. It has active members in Ireland, Australia and Anglo-Saxon countries, and it made its international ties visible by having always at least one of its vice-presidents, and altogether five out or more than 30 'fellows' from non-English speaking countries (see Table 1).

When the first 'International Encyclopedia of Higher Education' was edited in 1977 by an U.S. university president (Knowles 1977), $75 \%$ of the authors from topical essays were from the U.S., $14 \%$ from the UK and Canada-about half each -as well as $11 \%$ from other countries, among them less than half from other European countries (see Teichler 1980). Overviews on major publications on higher education compiled by the U.S. scholar Philip G. Altbach from the late 1970s onwards (see Altbach 1979), which aimed to look beyond what is available in the English language, suggest that one could have drawn from a larger pools of higher education researchers from various countries already at that time.

During the 1970s, two European associations were formed, that aimed at bringing together persons interested both in higher education research and in higher education policy and practice. First, the European Association for Research and Development in Higher Education (EARDHE) had an emphasis on teaching and learning (see for example Ritter and Kühn 1985); after some years of activities, it faded away in the 1990s, and its role was taken over by the International Consortium for Educational Development (ICED), a network founded in 1993 of more than 20 associations from all over the world, of experts in teaching and learning in higher education; it publishes the International Journal for Academic Development (IJAD).

Second, the European Association for Institutional Research (EAIR) was founded in 1979. Its foundation was inspired by the impressive development of 'institutional research' in the U.S., as will be discussed below, and started off as partner association of the AIR. As 'institutional research' of that type had not become a sizeable phenomenon in Europe, EAIR became an association that promoted the dialogue between higher education researchers and practitioners, notably in Europe (see Begg 2003). Its journal, Tertiary Education and Management, published predominantly the major contributions to their annual conferences for a couple of years (Kehm 2005). EAIR's broad European base is underscored, for example, by the fact that it honoured 8 European higher education researchers from 6 countries since the mid-1990s through distinguished memberships, honorary president positions or awards for outstanding contributions to research, and additionally three experts from three countries for various contributions to EAIR (see Table 1). 
Table 1 Key higher education researchers in Europe

Society for Research into Higher Education (SRHE): Vice-president from non-English speaking country (currently): Ulrich Teichler (Germany); fellows from non-English speaking countries: Marianne Bauer (Sweden), Gunnar Handal (Norway), Peter Maassen (the Netherlands and Norway), Ference Marton (Sweden) and Ulrich Teichler

EAIR: Distinguished memberships, honorary president positions or awards for outstanding contributions to research in recent two decades: Ron Barnett (UK), Guy Haug (France and Belgium), Ellen Hazelkorn (Ireland), José-Ginés Mora (Spain), Guy Neave (UK and France), Michael Shattock (UK), Ulrich Teichler and Mantz Yorke (UK); distinguished membership for various contribution to EAIR: Kary Hyppönen (Finland), Roddy Begg (UK) and Anita Ax (the Netherlands)

European authors in B.R. Clark: The Higher Education System (1983): Tony Becher (UK), Ladislav Cerych (France and Czech Republic) Maurice Kogan (UK), Harold Perkin (UK) and Gareth Williams (UK)

Frequently cited scholars in the Encyclopedia of Higher Education (Clark and Neave 1992) from Europe: Guy Neave, Maurice Kogan, Ulrich Teichler, Tony Becher (UK), Gareth Williams, George Psacharopoulos (Greece), Mark Blaug (UK) and Frans van Vught (the Netherlands)

CHER chairpersons since 1978: Ulrich Teichler, Guy Neave, Jean-Claude Eicher (France), Oliver Fulton (UK), Alberto Amaral (Portugal), Christine Musselin (France) and Patrick Clancy (Ireland); secretaries: Frans van Vught, Peter Maasen (both the Netherlands at that time), Jürgen Enders and Barbara M. Kehm (both Germany at that time) and Pedro N. Teixeira (Portugal)

European higher education researchers frequently named in M. Tight: Researching Higher Education (2012): Ronald Barnett, Rosemary Deem, Lee Harvey, Peter T. Knight, Michael Shattock, Malcolm Tight and Mantz Yorke (all UK); Ference Marton and Ulrich Teichler

European higher education researchers frequently named in M. Kwiek: Knowledge Production in European Universities (2013): Nicolas Barr, John Brennan, Roger Dale, Rosemary Deem, Maurice Kogan, Hugh Lauder, Guy Neave, David Palfreyman, Peter Scott, Michael Shattock, Paul Temple, Paul Trowler, Richard Whitley and Gareth Williams (all UK); Alberto Amaral, Ivar Bleiklie, Andrea Bonaccorsi, Jürgen Enders, Aldo Geuna, Ase Gornitzka, Jeroen Huisman, Ben Jongbloed, Georg Krücken, Marek Kwiek, Loet Leydesdorff. Peter Maassen, Kerstin Martens, Christine Musselin, Johan P. Olsen, Carlo Salerno, Bjorn Stensaker, Ulrich Teichler, Pedro Teixeira, Jussi Välimaa, Frans van Vught and Luc Weber (all other European countries)

Long-standing coordinating editors of higher education journals published in Europe: Guy Neave, Alec Ross, Maurice Kogan, Noel J. Entwistle, Malcolm Tight, Roddy Begg, Bjorn Stensaker, Jeroen Huisman, et al.

Award of the Comenius Prize for research achievements upon the occasion of the UNESCO World Conferences on Higher Education in 1998 to Europeans: Ladislav Cerych and Ulrich Teichler; European scholars members of scientific advisory committees of the UNESCO Forum on Higher Education, Research and Knowledge (2001-2008): Ivar Bleiklie (Norway), Maurice Kogan, Philippe Laredo (France), Francisco Michavila-Pitarch (Spain), Guy Neave, Baiba Rivza (Latvia), Helena Sebkova (Czech Republic), Sverker Sorlin (Sweden), Roland G. Sultana (Malta) and Ulrich Teichler

Members of the Academia Europaea: formerly: Tony Becher (UK) Maurice Kogan (UK); longstanding members: Peter Scott (UK) and Ulrich Teichler; recent members: Jürgen Enders (initially Germany, thereafter the Netherlands and UK), Simon Marginson (Australia and UK), Christine Musselin, Michele Rostan (Italy), Jussi Välimaa (Finland) and Marijk van der Wende (the Netherlands)

Coordinators of the ESF-sponsored project "Higher Education Looking Forward (HELF)"

(2005-2007): John Brennan (UK), Jürgen Enders, Christine Musselin, Ulrich Teichler and Jussi Välimaa; coordinators of the project consortia in the framework of the ESF-sponsored "Higher Education and Social Change in Europe (EuroHESC)": Ivar Bleiklie, Uwe Schimank (Germany), Ulrich Teichler and Jussi Välimaa 
While some major journals in this domain had been already established earlier in the U.S., various international journals on higher education in the English language are published in Europe since the 1970s: Higher Education (since 1972; now published by Springer, the Netherlands), a research journal covering the whole range of higher education research; Studies in Higher Education (since 1976, now published by Taylor \& Francis, UK), a research journal established by SRHE with emphasis on teaching and learning, curricula, etc., but covering other themes as well; Higher Education in Europe (1976-2009), published by the European Centre for Higher Education (CEPES/UNESCO), and since 2011 substituted by the academic journal European Journal of Higher Education (published by Routledge, UK); Journal of Higher Education Policy and Management (1978-2012), established and published by OECD; Higher Education Policy (since 1988, now published by Palgrave Macmillan, UK), established by the International Association of Universities (IAU); Tertiary Education and Management (since 1995, now published by Routledge, UK), established by EAIR. Additionally, the European Journal of Education (since 1975, now published by Blackwell, UK), coordinated by the European Institute of Education and Social Policy, France, comprises at least one thematic issue annually on higher education. Among these journals, the two with an exclusive academic thrust, i.e. Higher Education and Studies in Higher Education, had a clear dominance of authors from the U.S., the UK and other Anglo-Saxon countries, at least up to the 1990s.

When Burton R. Clark-along with Martin Trow one of the two most influential international 'father figures' for the development of higher education research in Europe (see notably Burrage 2010; Clark 1983) —invited in the early 1980s leading scholars to provide an account of the state of research in this domain worldwide (see Clark 1984), the majority of scholars were from the U.S. He chose five speakers from Europe, among them four from the UK and only one from continental Europe (see Table 1).

The growth of quantity and quality of higher education research since the 1970s was reflected in the second major encyclopaedia of this field, published in the early 1990s. Among the 18 most frequently cited scholars in the Encyclopedia of Higher Education (Clark and Neave 1992), eight were from Europe-five from the UK and three from other European countries.

The foundation of the Consortium of Higher Education Researchers (CHER) in 1988 certainly has contributed to improved communication among researchers and to growing research collaboration in Europe on matters of higher education, as well as increased international visibility of European higher education researchers. CHER aims at being the most visible international association of higher education researchers. Practically, it has a strong focus on Europe in various respects. More than three quarters of the members and similarly members of the board have been from Europe over the years. All chairpersons and secretaries were from Europe, and all annual conferences were held in Europe. Among the themes addressed in conferences and certainly in projects triggered two figure prominently, which are much more at the heart of higher education researchers in Europe than for example in the U.S., i.e. comparative research on higher education, as well as macro-system 
issues of higher education (societal expectations, the overall fabrique of the higher education system, steering of the higher education system and the role of government, etc.), while more research in the U.S. focus on meso-level and micro-level issues.

CHER brought together higher education researchers from a broad range of European countries. The seven chairpersons were from five different countries, while the five secretaries came from three countries (see Table 1). Ten or more members each in 2013 came from the UK, Germany and France, five and more from Norway, Portugal, Italy, Finland, the Netherlands and Austria, and smaller numbers each from more than a dozen other European countries (members from outside Europe not taken into consideration here). Overviews on participants and speakers at the CHER conferences over the years show also active involvement of European scholars from Belgium, Czech Republic, Hungary, Ireland, Poland, Serbia, Slovenia, Spain, Sweden and Switzerland (see Teichler 2013a, b).

Yet, the development of CHER shows as well that higher education research in Europe continued to be based for a long time on an institutionally relatively weak basis. CHER relied very much only on four sizeable institutes interested in international comparison and in macro-issues of higher education: the already above named CHEPS (the Netherlands) and INCHER-Kassel (Germany), as well as the Nordic Institute for Studies in Innovation, Research and Education (NIFU) in Oslo (Norway) and the Centre for Research in Higher Education Policies (CIPES) of the University of Porto (Portugal). Also, only less than 50 members of CHER are holders of a professor title in the domain of higher education (according to the denomination of their professorship or that of their unit) (see Teichler 2013b).

Actually, the relatively small size of the higher education research communities in the individual European countries was a major reason for the establishment of supra-national associations such as CHER. Often, the national community was considered to be too small to ensure a functioning platform of discourse. Even up to the present, there are only a few national or regional associations of higher education researchers in Europe.

Major segments, but certainly not the complete picture of institutions and programmes mostly active within the respective countries and within the home country language, became visible in the inventories of higher education research institutions and of academic master and doctoral programmes of higher education published in 2000, 2006 and 2014. The most recent inventory records 66 research institutions on higher education in Europe (as compared to 50 in the U.S.), among them 18 in the UK, one in Ireland and 47 in 20 non-English speaking European countries, as well as 22 programmes in Europe (as compared to almost 200 in the U.S.), among them 13 in the UK, one in Ireland and 8 in 6 non-English speaking European countries (Rumbley et al. 2014).

With the growing communication and cooperation among higher education researchers in Europe, English as the lingua franca gained momentum. From 1993 to $1997,21 \%$ of the articles in Higher Education, the internationally most visible and prestigious journal in this domain, were still written by UK authors and only $13 \%$ by authors from other European countries (Maassen 2000). In contrast, $29 \%$ 
of the articles published in 2001-2004 were written by authors from other European countries and only $12 \%$ by UK authors (Teichler 2005); as the journal had substantially grown in size, however, the absolute number of contributions from the UK did not decline, but that of the contributions from other European countries more than quadrupled. In 2010, eventually, $36 \%$ of the articles were from other European countries and $13 \%$ from the UK (Tight 2012).

Yet, authorships of conference presentations and journal articles, as well as countries addressed in English-language journals have remained grossly uneven across those European countries where sizeable higher education research exists. For example, scholars from the Netherlands and the UK, as well as from Finland, Germany and Italy comprised more than half of the speakers at CHER meetings during the first ten years (Kehm and Teichler 2013a). The above named overview on leading journals in the English language showed that the U.S., the UK, Australia and Canada comprised altogether half of the country cases addressed in comparative articles from 1992 to 2011 . While 230 articles report on the UK, only 44 address Germany, 37 the Netherlands, 34 France and 25 Sweden (Kosmützky and Krücken 2014).

The distribution by country looks more uneven if the analysis of publications is not based on a few leading journals, but rather on a broader range of English language-journals with a predominant Anglo-Saxon base. For example, Tight (2012) - drawing both from international and predominantly Anglo-Saxon publications - names five or more publications each of 14 authors, among them seven from the UK, two from other European countries and five from other regions of the world. In contrast, a Polish scholar (Kwiek 2013), summarizing the state of knowledge on higher education in Europe, names altogether more than 50 higher education researchers five times or more in his list of references, among them more from other European countries (22) than from the UK (14) and from other parts of the world (17) (see Table 1).

One might add that a different composition by country also shows up if one looks at the assessments of organisations outside academia. The UNESCO, when arranging its first World Conference on Higher Education in 1998, awarded the Comenius Prize to one U.S. and two continental European scholars. The Academia Europaea, co-opting excellent scholars from all disciplines, had or has currently altogether 10 higher education researchers as members, among them 4 from the UK and 6 from other European countries (see Table 1).

In Europe, higher education researchers of the United Kingdom and of Ireland publish mostly in English, and their academic achievements are fully visible in the English language. Higher education researchers from Finland, the Netherlands, Norway and Sweden often publish in English; many, but not all major academic achievements of prominent higher education researchers in those countries are visible in English. In contrast, more than nine tenth of the important academic publications on higher education are still published today in the respective native language in other large European countries, e.g. Germany, France and Italy, in most Southern European, as well as in Central and Eastern European countries, and one gets a good overview on the academic achievements of only few higher education 
researchers from those countries by examining publications in the English language.

This holds true, even though numerous efforts are made to make research in those countries more visible to the English-reading audience (see for example CHEPS et al. 2010; Klemencic 2014; Zgaga 2013). However, one can get a glance at higher education research in a broader range of European countries with the help of books with collections of essays, e.g. Festschriften, books based on the annual conferences of CHER, EAIR, etc. as well as various thematically focussed conferences, comparative projects, etc., because the editors often intend to include authors from a broad range of countries (see Table 2).

Table 2 Major collections of essays - Contributions to conferences, festschriften, comparative projects, etc. - Published by European higher education researchers since 2002

Enders, J. and Fulton, O. (eds.) (2002) Higher Education in a Globalising World: International Trends and Mutual Observations: A Festschrift in Honour of Ulrich Teichler. Dordrecht: Kluwer Academic Publishers

Amaral, A., Meek, V. L. and Larsen, I. M. (eds.) (2003) The Higher Education Managerial Revolution? Dordrecht: Springer

De Corte, E. (ed.) (2003) Excellence in Higher Education, London: Portland

Williams, G. (ed.) (2003) The Enterprising University: Reform, Excellence and Equity, Buckingham: SRHE and Open University Press

Sadlak, J. (ed.) (2004) Doctoral Studies and Qualifications in Europe and the United States: Status and Prospects. Bucharest: UNESCO-CEPES 2004

Bleiklie, I. and Henkel, M. (eds.) (2005) Governing Knowledge: A Study of Continuity and Change in Higher Education - A Festschrift in Honour of Maurice Kogan. Dordrecht: Springer

Gornitzka, A., Kogan M. and Amaral, A. (eds.) (2005) Reform and Change in Higher Education: Analysing Policy Implementation, Dordrecht: Springer

Marton, F., Hounsell, D. and Entwishtle, N. (eds.) (2005) The Experience of Learning: Implications for Teaching and Studying in Higher Education. Third (internet) edition. Edinburgh: University of Edinburgh

Krücken, G., Kosmützky, A. and Torka, M. (eds.) (2006) Towards a Multiversity? Universities between Global Trends and National Traditions. Bielefeld: Transcript

Meyer, J. and Land, R. (eds.) (2006) Overcoming Barriers to Student Understanding: Threshold Concepts and Troublesome Knowledge, London: Routledge

Teichler, U. (ed.) (2006) The Formative Years of Scholars, London: Portland

Tomusk, V. (ed.) 2006 Creating the European Area of Higher Education: Voices from the Periphery, Dordrecht: Springer

Cavalli, A. (ed.) (2007) Quality Assessment for Higher Education in Europe, London: Portland Enders, J. and van Vught, F. (eds.) (2007) Towards a Cartography of Higher Education Policy Change: A Festschrift in Honour of Guy Neave, Enschede: Center for Higher Education Policy Studies

Kehm, B. M. (ed.) (2008) Hochschule im Wandel: Die Universität als Forschungsgegenstand. Festschrift für Ulrich Teichler, Frankfurt a.M. and New York: Campus 
Table 2 (continued)

Shattock, M. (ed.) (2008) Entrepreneurialism and the Knowledge Economy: Diversification and Organisational Change in European Universities, Maidenhead: McGraw Hill and Open University Press

Taylor, J., Brites Ferreira, J., de Lourdes Machado, M. and Santiago, R. (eds.) (2008) NonUniversity Higher Education in Europe, Dordrecht: Springer

Amaral, A., Neave, G., Musselin, C. and Maassen, P. (eds.) (2009) European Integration and the Governance of Higher Education and Research, Dordrecht: Springer

Kehm, B. M. and Stensaker, B. (eds.) (2009) University Rankings, Diversity and the Landscape of Higher Education, Rotterdam and Taipei: Sense

Knust, M. and Hanft, A. (eds.) (2009) Continuing Higher Education and Lifelong Learning: An International Comparative Study on Structures, Organisation and Provisions, Dordrecht: Springer

Paradeise, C., Reale, C., Bleiklie, I. and Ferlie, E. (eds.) (2009) University Governance, Dordrecht: Springer

Sadlak, J., Hüfner, K., Pricopie, R. and Grünberg. L. (eds.) (2009) Topical Contributions and Outcomes, Bucharest: UNESCO CEPES

Davis, M., Devlin, M. and Tight, M. (eds.) (2010) Interdisciplinary Higher Education: Perspectives and Practicalities, Bingley: Emerald

Clancy, P. and Dill, D.D. (eds.) (2011) The Research Mission of the University: Policy Reforms and Institutional Response, Rotterdam and Taipei: Sense

Rostan, M. and Vaira, M. (eds.) (2011) Questioning Excellence in Higher Education, Rotterdam and Taipei: Sense

Slowey, M. and Schuetze, H. G. (eds.) (2012) Global Perspectives on Higher Education and Lifelong Learning, Milton Park: Routledge

Vukasovic, M., Maassen, P., Nerland, M, Pinheiro, R., Stensaker, B. and Vaboe, A. (eds.) (2012). Effects of Higher Education Reforms: Change Dynamics, Rotterdam: Sense

Engwall, L. and Scott, P. (eds.) (2013) Trust in Universities, London: Portland

Blömeke, S. Zlatkin-Troitschanskaia, O., Kuhn, C. and Fege, J. (eds.) (2013) Modeling and Measuring Competencies in Higher Education: Tasks and Challenges. Rotterdam, Boston and Taipei: Sense

Karlsen, J. E. and Pritchard, R. (eds.) (2013) Resilient Universities: Confronting Challenges in a Changing World, Oxford: Peter Lang

Zgaga, P. Teichler, U. and Brennan, J, (eds.) (2013) The Globalisation Challenge for European Higher Education: Convergence and Diversity, Centres and Peripheries, Frankfurt a. M.: Peter Lang Edition

Brankovic, J., Klemencic, M., Lazetic, P. and Zgaga, P. (eds.) (2014) Global Challenges, Local Responses in Higher Education: The Contemporary Issues on National and Comparative Perspective, Rotterdam: Sense

Goastellec, G. and Picard, F. (eds.) (2014) Higher Education in Societies: A Multi Scale Perspective, Rotterdam: Sense

Mattei P. (ed.) (2014) University Adaptation in Difficult Economic Times, Oxford: Oxford University Press 


\section{Higher Education Research not Visible in the Lingua Franca-The Case of Germany}

Germany is taken here as a case for showing the situation of higher education research in individual European countries. In this large country, a certain size and magnitude of higher education research is available. In relative terms, i.e. compared to the size of the population and of the higher education system, higher education research in Germany is clearly a smaller field than for example in Finland and Norway, but a larger field than for example in France or Italy.

It was a marginal field in Germany, as in many other countries, up to the 1960s. In the 1970s, institutionalisation moved in three directions: The establishment of centres for 'higher education didactics' at various higher education institutions, both in charge of research and service of staff and curriculum development, further the establishment of sizeable research units on higher education located outside academia, and finally a growing thematic area taken up individually by scholars from various disciplines. In contrast, only a single university in Germany had opted at that time for the establishment of a sizeable centre focussing on higher education research (see Goldschmidt et al. 1984; Oehler and Webler 1988; Over 1988).

Interest in systematic knowledge on higher education seems to have grown further in Germany since the 1990s. Research on higher education expanded moderately, but changed clearly in structure: There were fewer centres for 'higher education didactics' now, but some other research units within higher education institutions were established or grew in size.

The authors of a study on the state of higher education research published in 2003 (Gunkel et al. 2003) actually had invited scholars, who had published at least five times in this domain (according to a major bibliography) or had been professionally active for a few years in a unit specialized on higher education research, to contribute to a directory, if they view themselves as belonging to the category of higher education researchers. Actually, about 150 persons in Germany identified themselves this way. Less than half of them were academics fully specialized on higher education, and this proportion was even lower within professorial ranks. Only about $10 \%$ of the publications of these approx. 150 persons, which the authors had selected as their major ones, were not written in the German language, but rather mostly in English (cf. also subsequent overviews in Pasternack 2006; Zimmermann et al. 2008).

In recent years, higher education research has clearly expanded in Germany. One might estimate the number of scholars, who would identify themselves today as higher education researchers, as being at least twice as high as a decade ago. Some new research units and new professorships on higher education have been established. The Federal government created a regular scheme for the promotion of higher education research along its various previously existing modes of support for individual policy-relevant projects and a few institutions. The Gesellschaft für Hochschulforschung $(\mathrm{GfH} f)$, i.e. the association for higher education research in German-speaking countries, was established in 2006. A few institutions of higher 
education introduced master programmes focussing on higher education or having it as a sub-area. The number of doctoral candidates and young scholars in the related disciplines, who opted for higher education as their thematic focus, increased substantially.

In 2010, a survey was undertaken of the almost 200 persons participating in a network of young scholars or professionals active in research on higher education. Most of the respondents were academic staff still working on or having already completed a doctoral dissertation thematically focussing on higher education. As no doctoral programme on higher education exists in Germany and as the dissertation has to fit in the disciplinary structure, more than one third of the dissertations were allocated to sociology and more than one fifths to economic fields, while the others spread over a broad range of disciplines. More than one third reported that their first supervisor and about a quarter that their second supervisor is a professor specialized on higher education. Most of the junior higher education researchers were junior academic staff at that time, among them more than a third in a unit within academia or outside academia that is specialized on higher education research (Steinhardt and Schneijderberg 2014).

In 2012, a mapping of higher education research in Germany was initiated by the GfHf. It named less than ten units as the institutionalized core of higher education research. First and second, two research centres within universities that are specialized in this domain: The Internationale Zentrum für Hochschulforschung (International Centre for Higher Education Research) of the University of Kassel (INCHER-Kassel), established in 1978, and the Institut für Hochschulforschung Wittenberg (HoF, Institute for Higher Education Research Wittenberg) at the University of Halle-Wittenberg, established in 1997 in the wake of the transformation of an earlier East German research institute. Third and fourth, two research units on higher education embedded into the educational sciences of the Humboldt University Berlin and into sociology at Constance University. Fifth and sixth, two government-linked institutes: Bayerisches Staatsinstitut für Hochschulforschung and Hochschulplanung (IHF, Bavarian State Institute for Higher Education Research and Planning), established in 1973 in Munich, and Deutsches Zentrum für Hochschul- und Wissenschaftsforschung (DZHW, German Institute for Higher Education and Science Research), founded in 2013 in Hannover and Berlin through a process of merger of two previous institutes abbreviated as HIS and iFQ.

Three further institutions are viewed to be somewhere between the 'centre' and the 'periphery' of higher education research. Seventh, the Centrum für Hochschulentwicklung (CHE, Centre for Higher Education Development) in Gütersloh, established in the early 1990s as a consultancy institution with some research activities. Eighth, centres for 'higher education didactics'-with the Hochschuldidaktisches Zentrum (HDZ) of the Technical University of Dortmund as the strongest unit. Ninth, units of science research, among them notably the research group "Science Policy" of the Wissenschaftszentrum Berlin für Sozialforschung (WZB, Social Science Research Centre Berlin).

In addition, research on higher education is undertaken in a 'periphery': Individual scholars in the respective disciplines (the report only names a relatively 
short list of professors with a long-term focus on higher education research), research institutes and units in related fields, e.g. educational research, and systematic information gathering within various areas of policy and management (e.g. higher education evaluation, higher education development and higher education management), (cf. also various essays on the state of higher education research in Germany in Pasternack 2014; see the summary of the unpublished report in Winter 2014).

As regards other visible activities, the mapping report pointed out that six master programmes existed in Germany in the area of higher education and research (in Speyer, Hannover, Osnabrück, Bielefeld, Hamburg and Oldenburg). Actually, the only master programme in this domain in Germany taught in English (the MAHE programme in Kassel) was discontinued in 2013 after six cohorts. Most of the existing master programmes, however, have a practical emphasis of training for higher education and research management rather than for higher education research and science research.

There are a few journals on higher education. They either address concurrently academics, policy makers and practitioners (e.g. Das Hochschulwesen), or have a clear emphasis on policy makers and practitioners (e.g. Deutsche Universitätszeitung and Forschung \& Lehre), or those having an academic emphasis are published by single institutes (e.g. Beiträge zur Hochschulforschung published by IHF).

In looking at the approximately two dozens most highly visible senior higher education researchers in Germany since the 1960s (see Table 3) we certainly can state that the majority was or is interested in the state of research worldwide. But the majority did not see any need to publish in the English language or to be closely embedded in international networks in order to undertake successfully academically highly ambitious and practically highly relevant research.

Table 3 Major senior scholars in the domain of higher education research in Germany

\begin{tabular}{l} 
'Nestors': Dietrich Goldschmidt and Ludwig Huber \\
Core higher education researchers (mostly with a social science background): Hansgert Peisert, \\
Christoph Oehler, Ulrich Teichler, Jan-Hendrik Olbertz, Andrä Wolter, Jürgen Enders (Germany, \\
the Netherlands and UK), Barbara M. Kehm (Germany and UK), Peer Pasternack, Georg \\
Krücken, Ulrich Wilkesmann and Philipp Pohlenz \\
Higher education researchers specialized higher education didactics: Sigrid Metz-Göckel, \\
Carl-Hellmut Wagemann, Johannes Wildt, Margret Bülow-Schramm and Wolff-Dietrich Webler \\
Coordinators in state-related institutions: Heinz Griesbach, Klaus Schnitzer, Michael \\
Lesczczensky, Edith Braun, Stefan Lullies and Lydia Hartwig \\
\hline Representatives of various disciplines: Werner Thieme, George Turner (law), Anke Haft, Rainer \\
Künzel, Gerd Grözinger, Dieter Timmermann (economic fields), Uwe Schimank (sociology) and \\
Peter Lundgren (history) \\
Scholars predominantly active in consultancy: Detlef Müller-Böling and Frank Ziegele \\
Science researchers: Peter Weingart, Hans-Dieter Daniel (Germany and Switzerland) and Stefan \\
Hornbostel
\end{tabular}




\section{Thematic Areas of Higher Education Research}

There is no widespread agreement as how to classify higher education research. Yet, some examples might show that most classifications opted for are not so far apart.

In some instances, higher education research is described as an 'archipelago', a 'schism' or 'two continents', i.e. as being divided between two thematic areas and research approaches: teaching and learning on the one hand, and on the other higher education policy and organisation (e.g. Horta and Jung 2013; Macfarlane 2012). Other analyses suggest that there are three major foci of analysis: (1) teaching, learning, curricula, competences, as well as teachers and learners, i.e. studies relevant for the teaching function of higher education, (2) governance, management, etc., i.e. studies relevant for decision-making and organisation, and (3) the higher education system and its societal context.

With a view of the areas of specialisation among higher education researchers, a classification of four 'spheres of knowledge' was proposed: (1) quantitativestructural aspects, (2) knowledge and subject-related aspects, (3) person-related and teaching and learning-related aspects and (4) aspects of institution, organisation and governance (Teichler 1996).

In the framework of reviews of publications, a more disaggregated list of themes tends to be preferred. For example, Tight $(2003,2012)$ opted for eight themes: Teaching and learning, course design, the student experience, quality, system policy, institutional management, academic work, knowledge and research. In an analysis of 15 English-language journals, he classified $31 \%$ of the articles published in 2010 as addressing course design, $24 \%$ student experience, $13 \%$ academic work and less than one tenth each of the other themes (Tight 2012).

The journal Research into Higher Education Abstracts, published by SRHE, also has established a list of eight - partly similar - categories. There were in 2014: (1) National systems and comparative studies, (2) institutional management, (3) curriculum design, (4) research, (5) students, (6) staff, (7) contributory studies and research approaches, (8) teaching learning and assessment. One additional category employed for a couple of years has been eventually dropped: finance and physical resources.

It might be worth as well mentioning in this context the range of themes addressed in a major historical account of the development of universities in Europe since 1945 (Rüegg 2011): changing the major themes discussed, patterns of the higher education system, relations with authority, management and resources, teachers, admission, education and students, student movements and political activism, graduation and careers, the various disciplines, and "From the University in Europe to the Universities of Europe" (Barblan 2011).

The thematic range certainly might look wider, if one paid attention to research on higher education undertaken in the framework of various disciplines. Actually, more than 20 "disciplinary perspectives on higher education" were named in the 1992 encyclopeadia: anthropology, comparative education, economics, higher 
education studies (i.e. the 'discipline' in the centre of this article), history, law, linguistics and rhetorical studies, literature, macrosociology, organization theory, philosophy, policy analysis, political economy, political science, public administration science studies, social psychology and women's studies (Becher 1992).

According to a review of higher education research in Europe published in the early years of the 21 st century, research in this domain has been quick in taking up the themes currently discussed publicly. At times, higher education and economic growth, inequality, students' views and attitudes, graduate employment, diversification, management, evaluation, etc., were highly on the agenda for a few years, and many research projects shed light on the respective themes (see Teichler 2005). According to more general categories than the ones presented above, however, a relatively high degree of continuity in higher education research could be observed with one exception: an increase of research on internationalisation of higher education (see Kehm and Teichler 2007; Teichler 2010b) - a change of research reflecting a change of reality, i.e. an internationalisation trend in higher education and research (see Scott 2008).

Two recent lists of themes seem to be most suitable to indicate the recent priorities of higher education researchers. First, an analysis was undertaken of the themes addressed in 291 articles published in the years 2011 and 2012 in four major international higher education journals published in Europe (Teixeira 2013). Though this analysis comprises also articles written by scholars from other regions of the world, it certainly mirrors by and large the recent thematic priorities of higher education researchers in Europe:

- $15 \%$ system regulation/government and higher education institutions,

- $17 \%$ institutional analysis, governance, management,

- $17 \%$ quality, evaluation, assessment,

- $5 \%$ funding and economic issues,

- $9 \%$ access, equity,

- $24 \%$ students' satisfaction, performance and evaluation,

- $14 \%$ academic profession, and

- $12 \%$ other themes.

Second, an analysis was undertaken of the changes of the thematic interests of members of the Consortium of Higher Education Researchers (Kehm and Teichler 2013a). As already stated above, about three quarters to CHER members are Europeans. A comparison of statements made by the scholars themselves in the member directories in 1992 (2.0 themes on average) and 2012 (2.6 themes) shows, in contrast to be above named observation, a substantial thematic change over time:

- Interest increased most dramatically in Internationalisation, mobility, etc.: from 4 to $24 \%$ within two decades,

- Also, we note a substantial increase of interest-from 27 to $48 \%$-in Governance, management and organisation,

- Four areas can be named, where a moderate increase of interest can be observed: Higher education systems (from 28 to $38 \%$ ), Study programmes, teaching and 
learning (from 13 to $20 \%$ ), Academic profession and work (from 11 to $17 \%$ ) as well as Access, students and graduates (from 18 to $23 \%$ ).

- There are five areas, however, where figures hardly changed over time or even a moderate decrease can be observed: Quality, evaluation, etc. (25\% at both points in time), Knowledge, research and transfer (from 16 to $13 \%$ ), Higher education research, theories, methods, etc. (from 13 to $15 \%$ ), Higher education policies, reforms (from 35 to $28 \%$ ), and Funding, resources, etc. (from 13 to $9 \%)$.

Table 4 Major issues addressed by European higher education researchers

The changing composition of power in higher education: The role of governments, external stakeholders, the market, and institutional management and the academic profession

The consequences of increasing competition mechanisms, market steering, incentive steering, privatisation, indicator-based policies, 'commodification'

Evaluation: modes, quality and validity, impact, the changing concepts of quality and relevance

Diversity of higher education: 'World class universities' and rankings, the profiles and characteristics of individual higher education institutions, pressures for diversification versus 'isomorphism' and 'academic drift', the impact of external demands and internal dynamics on the overall pattern of the higher education systems

Changes of learning and assessment: emphasis on 'competences' and 'learning outcomes', changes of assessment systems, potentials and limit of performance and achievement testing, the students as targets and as actors in the system of study programmes, teaching and learning

The changing role of research undertaken in universities: application drift, changing balance of disciplines, links of research to technology transfer and innovation, the changing role of the humanities and social sciences, etc.

The changing educational and training role of higher education: Consequences of expansion, dynamic occupational change, between an elite-reproduction, meritocratic and egalitarian function, challenges of life-long learning, the impact of study conditions and provisions on graduate employment and work, the links between levels of study programmes and degrees and the occupational structure

The changing function of higher education: Beyond knowledge production and dissemination, e.g. "service functions"

Higher education and Europe: convergence of structures, modes of governance and substance of teaching and research? Increasing similarity of quality or persistent inequality between national systems? Similarity or differences of the various national and supra-national policy rationales? The weight of national system persistence, Europeanisation and globalisation, impact of worldwide developments on higher education in Europe

The effects of higher education policies and reforms approaches - strategies, complexity of actors, implementation, known and unknown system dynamics, continuity and change, learning from intended and unintended effects?

Trends of visible internationalisation in higher education - migration, mobility, cross-border communication and cooperation, change of use of languages, international education, socialisation towards intercultural understanding, the overall impact of internationalization

The academic profession: changing expectations and pressures, changing status and self-perception, professionalization and changing tasks, between 'pursuit of knowledge and pursuit of revenue', changing academic careers

Doctoral education: Expansion, changing role for academia and other profession, changing modes of education, training and independent research work 
Certainly, one has to bear in mind, and this is visible when these figures are compared to those presented in various bibliographic analyses undertaken by Tight (2003, 2012), that CHER membership only includes a small proportion of higher education researchers active in the area of teaching, learning, curricula, etc.

A livelier picture of research in Europe can be presented, if one looks at the key issues of attention and concern. The author of this article, therefore, presents a list of themes in Table 4, which he observes as frequently discussed in books and articles published by higher education researchers or having been the focus of conferences in Europe in recent years.

Altogether, we can conclude that teaching, learning, curricula, competences, etc. is a long-standing priority area of higher education research in Europe. Research on governance, management and related themes has some tradition, but certainly grew over the years. Research on various issues of internationalisation was a marginal area up to the 1980s and became a priority area in recent years. Though these three areas play a substantial role in concurrent higher education research in Europe as far as visible in the English language, one cannot argue that they have pushed other areas aside. All other themes together comprise clearly more than half of the research interests expressed and the research activities undertaken.

\section{Types of Institutional Bases and Analysts}

As already pointed out, it is difficult to establish a map of institutions and persons involved in higher education research, because the settings are varied and the borderlines are fuzzy. This is all the more true for Europe, because long traditions are lacking and the scene varies substantially by country.

As regards the U.S., i.e. the country with a long tradition and an enormous quantity as far as higher education research is concerned, El-Khawas (2000) perceived a clear pattern of three separate sectors:

- "Research": Academically-based higher education research is often institutionalised in university units of teaching and research. Most frequently, master and/or doctoral programmes are the educational core activities, and most of them are institutionalised in the U.S. within departments/schools of education; potentials for academic research on higher education, thus, are alimented by these study programmes. Academics put emphasis on theoretical and methodological quality, irrespective whether they favour a pursuit of knowledge for its own sake or whether societal relevance plays a role in their research activities.

- "Practice": Many institutions of higher education in the U.S. establish units, often under the supervision of key managers in the individual university, and initiate analyses, which are expected to provide action-oriented interpretation of the findings and are considered as important feedback for the enhancement of teaching and learning, research, management, etc. 
- "Policy": Government or other supra-institutional actors (associations of universities, professional organisations, and various external stakeholders) in the U. S. have their own information and policy analysis units or sponsor such types of analyses expected to enrich the plausibility of policy processes through systematic collection of information, policy-driven interpretations, policy scenarios, etc.

In looking both at the institutional basis and the character of work, Teichler (1996) suggested a typology comprising six types of higher education experts:

- The discipline/department-based occasional researchers on higher education: They consider their departmental and disciplinary colleagues as their relevant peers. They embark on higher education as one theme of research among others. They might be strong in theory and methodology, while their research often lacks in-depth field knowledge, and many of them are not interested in the practical relevance of research.

- The continuous discipline-based higher education researchers: The discipline is a core element of their identity as well, but they focus - in contrast to the first type - on higher education for a long period or all over their academic life. They acquire sound field knowledge, and some of them might be interested to serve both academic quality and societal relevance.

- The scholars based in a higher education research institute or unit: Scholars in such an institution, as other theme-based scholars in theme-based units within or associated to academic institutions, have to strike a balance between academic recognition in terms of theoretical and methodological foundation on the one hand, and in-depth field-knowledge and practical relevance on the other hand.

- The applied higher education researchers: Similar to the above named type, they are predominantly or at least strongly involved in knowledge generation, for example as 'institutional researchers' and 'policy researchers', but this might be linked to practical tasks, e.g. 'staff development' or other service or administrative functions, and their reputation has to be based on the utility of their knowledge generation.

- The consultants of higher education: They have to draw from all kinds of systematic knowledge, possibly in part from own activities of knowledge generation, or practical experience, and to serve on this basis as advisors for policy makers and practitioners.

- Finally, the reflective practitioners: They might be politicians, university leaders, administrators, 'higher education professionals' and scholars in others disciplines, who consider themselves as experts in higher education. Some of them are actively involved part-time in collecting and systematizing knowledge on higher education and publishing in this domain, but even if this is not the case, they are strongly involved-as compared to other practitioners-in absorbing and 'digesting' systematic knowledge.

In an analysis of higher education research in Europe, six institutional settings of higher education were named (Teichler 2005): (1) Research and practice combined 
(e.g. centres for 'staff development'), (2) Institutional research, (3) Research alimented by teaching (e.g. sub-units of-for example educationaldepartments/schools, as often found in the U.S. and in China), (4) Nationally sponsored research institutes (such as the above named NIFU in Norway and DZHW in Germany), (5) University-based centres (such as the above named CHEPS in the Netherlands and INCHER-Kassel in Germany), and (6) sub-units within research units of a broader thematic or disciplinary framework, established outside or within higher education institutions (e.g. higher education research within the Institute de Recherche sur l'Economie de l'Education (IREDU) of the Université de Bourgogne in Dijon, France, and within the Research Unit for Sociology of Education (RUSE) of the University of Turku, Finland).

In describing higher education research in Europe more concretely, we might point out the characteristics in Europe as compared to the above picture provided for the U.S. Five such characteristics might be named.

First, there are only few master and doctoral programmes on higher education in Europe (cf. Maassen and Pausits 2013). As a consequence, research in this domain in Europe hardly is alimented by teaching on higher education. Also, if professor positions have the thematic focus of higher education at all, hardly any department or institute has more than a single professorship in charge of this thematic area.

Second, there are only a few European countries where the study of higher education is predominantly embedded in educational departments or educational research. This holds true for the UK and Finland, but not for France, Germany and many other European countries. Instead, research on higher education is linked to sociology, economics and business study, law, etc. (e.g. CHEPS to public administration and INCHER-Kassel to sociology).

Third, sizeable units of higher education research are established outside higher education institutions in some European countries. This holds true, for example, for the above named NIFU in Norway as well as DZHW and IHF in Germany. In various instances, additionally, institutes with a broader thematic focus might be in part involved in higher education research, e.g. educational, labour market and youth research institutions. These institutions, as a rule, they have a stronger applied emphasis than research based in academic units of universities.

Fourth, there is hardly any institutional research in Europe in terms of defined positions and units within the administrative realm of higher education institutions, with the explicit task of undertaking research aimed at directly serving reflection and practical action. There are a few positions and units of that kind, though, but more often administrators undertake such activities as part of their job role. In comparison to the U.S., we observe almost an "absence of any collective understanding of the meaning of institutional research" (Taylor et al. 2013) in Europe; however, some activities in this domain began to spread recently, and the Higher Educational Institutional Research Network (HEIR), established in 2008, has members notably in the UK and Ireland. In contrast, analyses undertaken by practitioners in European higher education, which can be viewed a functionally equivalent to institutional research, have been also described as more conceptual, more reflective and more varied than in the U.S. and thus, as providing the 
opportunity to contribute to more fundamental improvement in higher education (Klemencic and Brennan 2013).

Fifth, there is a substantially growing involvement of 'higher education professionals' in activities of more or less systematic information generation on higher education in Europe. While university administrations as well as governments and stakeholder organisations in Europe had small numbers of high-level administrators for a long time as compared to the U.S., we note a dramatic increase of highly qualified professionals in many European institutions of higher education in recent years, who are not academics, but have to have an in-depth understanding of the core functions of higher education, i.e. teaching and research in the various disciplines, in order to function properly in their service or management-support roles (Kottmann and Enders 2013). Often, they are just called according to their specific areas, i.e. quality managers, career officers, international officers, etc., while scholars analysing this phenomenon opt for various umbrella terms such as 'middle-level managers' or 'higher education professionals' (Gornitzka and Larsen 2004; Macfarlane 2011; Meek et al. 2010; Roesser 2004; Schneijderberg and Merkator 2012; Whitchurch 2009).

A study recently undertaken in Germany shows that the number of higher education professionals has reached about two-thirds of the number of professor positions at universities, whereby about one third of these professionals are doctoral degree holders. Only $7 \%$ report that they are actively undertaking research, but more than half seem to be involved in 'monitoring', 'evaluation' and other forms of systematic information gathering (Merkator and Schneijderberg 2012); one might assume that systematic information gathering plays even a stronger role among higher education professionals employed outside higher education institutions, e.g. in government, umbrella organisations, stakeholder organisations and consultant agencies.

In sum, there is only a relatively small number of persons in Europe who are officially defined as higher education researchers - either as academics primarily in charge of higher education as a field of research and possibly teaching, or as applied researchers in institutional settings close to management and policy. Rather, higher education researchers in Europe are predominantly those who have opted to be higher education researchers, though they have not any irrefutable-academic or administratively based-professional mandate of undertaking higher education research. Thereby, a clear dividing line is often lacking in Europe between higher education research protected by academic freedom or not being protected that way, as well as between a basic or applied research function. Altogether, visible higher education research experiences a growth in Europe, but this trend seems to be small as compared to the - less clearly visible - growth of other more or less systematic information collection (statistics, 'reporting'. 'monitoring', 'evaluation', creation of 'indicators', 'best practice reports', etc.) undertaken by higher education professionals in policy and practice.

Altogether, higher education research in Europe is in a contradictory situation. On the one hand, it lives in an academic Zeitgeist where the search for academic recognition as excellent according to pure academic criteria prevails and 
formalized assessments according to such criteria have become more and more forceful. As a consequence, for example, several higher education journals have recently drifted from being a forum for both scholars and reflective practitioners, towards criteria and processes, which signal academic purity and excellence. On the other hand, higher education research cannot avoid competing for funds and public recognition with a dramatically increasing number of higher education experts involved in various kinds of information gathering assumed to provide useful 'evidence' for higher policy and practice, and therefore underscores its practical utility (cf. Teichler 2014a).

\section{European Communication and Cooperation Within Higher Education Research and with Higher Education Policy and Practice}

In examining how higher education researchers communicate and cooperate with their colleagues across Europe or world-wide, and how higher education research interacts with policy and practice across borders, we have to bear in mind, as already pointed out initially, that higher education research tends to have a strong national emphasis. This reflects the fact that-irrespective of the global and universal elements in higher education - many features of higher education which are addressed in higher education research, e.g. institutional patterns, governance, funding, study programmes, and personnel policies, are predominantly shaped on the national level. As a consequence, the variety of higher education systems across countries is striking - a fact which justifies the analysis focus on single national higher education systems and concurrently increases barriers as far as in-depth comparative analysis is concerned.

Europe, however, has experienced since World War II a chain of supra-national higher education policies of stimulating the growth of similarities and of increasing border-crossing interaction in higher education. These policies and their actual impact on higher education have clearly called for increasing European and international perspectives in higher research. We might name four waves of European higher education policies initiated by various supra-national actors (Teichler 2010a):

- First, efforts were made since the 1950 s to increase mutual understanding between the European countries by facilitating student mobility. The Council of Europe took the lead and later cooperated with UNESCO and the European Commission in taking care of conventions regarding the recognition of study (linked to access, temporary student mobility and mobility after graduation) across European countries.

- Second, a multitude of activities were coordinated notably by OECD since the 1960s to seek for common directions of modernisation of higher education in the wake of its expansion and its growing relevance for economic development. 
For example, efforts of diversifying higher education in Western European countries were strongly influenced by these policy initiatives.

- Third, the European Community/Union became a major player of European higher education policy in the 1980s and 1990s with activities of stimulating mobility and cooperation, whereby ERASMUS support for temporary intra-European student mobility turned out to be the flagship of programmes.

- Fourth, the governments of the individual European countries decided in the late 1990s to strive for system convergence in the framework of what is called the "Bologna Process". Concurrently, the European Union advocated a "Lisbon Process" with the aim of increasing substantially the funding of research and technology across countries.

The growth of supra-national policy initiatives in Europe could be expected to be highly important for higher education research, because supra-national actors tended to be more strongly interested in systematic information collection on higher education than national policy actors (see Sadlak and Hüfner 2002) — obviously due to the fact that nobody on the international arena would trust the first-hand experiences of the policy makers and practitioners to the extent we still can observe on national level in many individual European countries. Moreover, supra-national higher education policy actors tend to advocate 'evidence-based' approaches more strongly than national policy actors, because they have to rely more strongly on the power of the argument than on political power as such.

As a consequence, many European higher education researchers were already strongly involved in stock-taking and policy formulation activities, before international communication between higher education researchers and a comparative project began to flourish. Actually, one of the motives to establish CHER as an international forum of higher education researchers was not to meet each other only under policy objectives at events arranged by international organisations, but also in settings aimed at enhancing the academic quality of knowledge generation in this domain (see Teichler 2013b).

Without being able to pinpoint in detail the complexity of specific trends and actions at specific points in time, we can argue that the readiness for a European dialogue and for cooperation between higher education research and higher education policy and practise increased visibly since about the 1980s due to:

- a higher density and forcefulness of supra-national policies in higher education,

- a gradual erosion of the formerly widespread belief within the individual European countries that higher education in their respective country is 'non-comparable' and, instead, increasing attention being paid to possible 'global' or 'convergent' trends of 'modernization',

- a growing intra-European interaction in higher education and an increasing inclination also of researchers in the behavioural and social sciences to communicate and cooperate across borders, and

- an increase of funds on the European level for undertaking comparative analyses, as well as analyses of supra-national features in higher education. 
Organisations such as OECD, UNESCO and the Council of Europe continued or enlarged 'think tank' projects where higher education researchers play a major role (cf. Scott 2008; see the results of recent projects in Altbach et al. 2009; Meek et al. 2009; OECD 2008, 2009). And the European Union became a highly visible actor in the communication and cooperation between higher education policy and higher education research.

A detailed analysis was undertaken in 2004 about EU-funded higher education research - either initiated by the European Commission or by other political actors (notably those responsible for the Bologna Process) with financial assistance by the EU, as well as those initiated by higher education researchers (Van der Wende and Huisman 2004). No corresponding analysis has been undertaken for the subsequent years. Some major trends and major approaches, though, can be named here, which are indicative for the situation as a whole.

First, the European Commission itself commissions studies for the purpose of 'evaluation' and 'monitoring' of the major EU programmes. This has been often the case as regards ERASMUS, i.e. the largest of the educational support programmes, where evaluation must be undertaken for the preparation of the decision, whether the programme is continued, modified or discontinued after a few years. Actually, the largest and most ambitious studies of ERASMUS have been undertaken or led by higher education researchers (CHEPS et al. 2008; Huisman and van der Wende 2004-2005; Janson et al. 2009; Rosselle and Lentiez 1999; Teichler and Gordon 2001; Teichler and Maiworm 1997).

Second, there are various modes and channels for the EU to initiate policy-related analyses or for higher education researchers to apply for financial support of such analyses. For example, higher education researchers from six European countries have recently collaborated in this framework in a study on university-industry relationships (Mora et al. 2010).

Third, the European Commission supports some projects in this domain in the framework of research promotion. While EU research promotion had been confined to the natural sciences for a long time, social sciences have been eligible for support since 1995. The first major project supported that way was a comparative survey on graduate employment and work (Schomburg and Teichler 2006; Teichler 2007), which was followed by a second one five years later (Allen and van der Velden 2011; see also Mora et al. 2013). A study on internationalisation policies and activities of various European countries (Huisman and van der Wende 2004-2005) was also among the first ones funded in this framework.

Fourth, the European Commission funded - in coordination with the Bologna Follow Up-Group (BFUG), i.e. the policy coordinators of the Bologna Process between the ministerial conferences - various analyses of the reforms linked to the Bologna Process. Most of these analyses, however, were not open to higher education researchers. Rather, the EU asked its own information agency, i.e. EACEA -Eurydice, and one stakeholder organisation participating in the BFUG, i.e. the European University Association (EUA), to undertake systematic accounts of the extent to which the Bologna reform objectives actually were realized (see for example Eurydice 2010; Sursock and Smidt 2010). In three major recent studies 
and publications on the Bologna Process, however, the research activities and the interpretations of higher education researchers became highly visible:

- The Flemish government initiated - in preparation of the 2009 Leuven conference-a collection of papers, in which European higher education researchers commented the developments and possible futures of the Bologna Processnotably in the areas of governance, quality, mobility and diversity (Kehm et al. 2009).

- In preparation of the 2010 Budapest and Vienna conferences, two research centres and a consultancy agency undertook a so-called "independent assessment" of the Bologna Process within the first ten years (CHEPS et al. 2010).

- In preparation of the 2012 Bucharest conference, many higher education experts were invited to write analyses on key themes of the Bologna Process. Actually, more than 50 articles addressed themes such as the principles of the European Higher Education Area, teaching and learning, quality assurance, mobility, governance, funding, diversification and the future of higher education (Curaj et al. 2012). According to those responsible, this activity "aimed at bringing the researchers' voice into higher education international level policy making", and it gave "an unprecedented opportunity for researchers dealing with higher education matters to interact and contribute to the political process shaping the European Higher Education Area, as well as national policy agendas" (Deca 2012, p. v). A similar project is underway in 2014.

Altogether, many higher education researchers in Europe got involved in comparative analyses or analyses on cross-cutting developments. Some projects were strongly shaped by the request of those supporting and commissioning the projects, while others were initiated and strongly reflected the researchers' notions and intentions. By and large, European higher education researchers seized this state of affairs as an opportunity to undertake studies that looked across national borders, and they took for granted that they had to strike a complicated balance in these projects between academic criteria of theoretical and methodological quality and objectives of practical relevance, between the notions of practical relevance held by the higher education researchers and those held by the policy actors funding the projects, and between the desirable conditions for high-quality projects and actually prevailing time and financial pressures.

Yet, critique is widespread among higher education researcher as regards the conditions these European projects are exposed to:

- First, the decision-making setting as regards the award of such projects is viewed by many higher education researchers as creating a disadvantage for them and an advantage for consulting firms and external stakeholder organisations.

- Second, the rules, the administrative surveillance and the financial controls of the projects are viewed as being hypertrophic. These mechanisms on EU level obviously are far more time-consuming and resource-binding than respective 
mechanisms regarding projects funded by national governmental agencies or by national public research promotion systems.

- Third, some projects are viewed as so highly prescribed thematically and methodologically by the sponsoring or commissioning actors that hardly any room is left for improvement due to the expertise of those undertaking the study or due to learning processes in the course of the project.

- Fourth, the policies of supporting such projects are viewed as changing too quickly and not taking care of continuity. Thus, opportunities of improving the state of knowledge through regular inquiries are missed, for example repeated surveys in order to examine change over time - as up to the present they are only established as regards student life in various European countries (Orr et al. 2011). For instance, the above named surveys of ERASMUS students or graduate employment and work were suitable to be repeated after a while, but were not transformed into a regular information system.

- Fifth, a strong ambivalence is felt as regards the interface between research and policy (see the systematic discussion of this theme in Amaral and Magalhaes 2013; Gornitzka 2013) as regards the use of research findings. To what extent is there an openness for surprising and even policy-challenging facts? To what extent is there interest in a creative dialogue between researchers and actors in the system as regards the interpretation of findings? Do analyses have primarily a symbolic rather than an evaluative value?

Altogether, higher education researchers often consider themselves to be viewed by policy makers as being just one of many interchangeable experts. Even if an activity is undertaken from the policy "aimed at bringing the researchers' voice into higher education international level policy making", as reported above, the higher education researchers conclude that more than half of those invited to raise their voice are not higher education researchers.

Of course, the higher education researchers know that many policy actors and practitioners view the higher education researchers critically. Suspicion is widespread that practical relevance is not high on the researchers' agenda, that they exaggerate quality standards and that they tend to present their own political preoccupations as research findings, etc. (see also critique named in Scott 2000). There are reasons on both sides not to consider the interface between research and policy as being a smooth operation.

One should add, however, that there are some opportunities for collaborative research of higher education researchers in Europe without the ambivalences of policy-initiated or policy-funded research. The biggest activity in this domain in recent years was funded by the European Science Foundation (ESF) - the European association of the major research promotion agencies in the individual European countries. In 2006, some higher education researchers applied successfully for the support of the "Higher Education Looking Forward (HELF)" project: for collaboration through conferences and joint writings of analyses on the possible futures of higher education and the respective future tasks of higher education research (see Brennan and Teichler 2008). Subsequently, funds were made available for four 
consortia of higher education researchers from 2009 to 2012 to conduct research on "Higher Education and Social Change in Europe (EuroHESC)". In this biggest collaborative activity of higher education research in Europe ever undertaken so far, more than 100 scholars addressed governance of higher education, higher education and knowledge society, and the academic profession in Europe. Currently, two books based on these projects (Teichler and Höhle 2013; Kehm and Teichler 2013b; Fumasoli et al. 2015) and many articles are available. Prior experiences in such international consortia of higher education research suggest that the projects are likely to last substantially longer than the major funding periods, but that eventually a multitude of results can be expected (see Teichler 2014b).

\section{Concluding Observations}

In sum, higher education researchers in Europe experience similar trends on the European level as on the national level, but even more striking than in their national arena. Higher education research experiences some growth, somewhat better conditions and somewhat more public attention and recognition. This, however, is embedded into a much more substantial growth of other higher education experts involved in some way or other as well in the - more or less systematic - generation of knowledge and into the expectation that enhanced knowledge on higher education has to be visibly useful. There are no simple answers to the questions: to what extent do these conditions serve the enhancement of higher education research? And to what extent do these conditions of knowledge generation serve a desirable future of higher education?

Some years ago, the dominant development trend of higher education research in Western Europe has been characterized as "From policy advice to self-reflection" (Frackmann 1997). Neither the "ivory tower" nor the mere policy advice are the dominant aim of higher education researchers, but rather the enrichment of joint reflection of the state of higher education on the part of the higher education researchers and the higher education policy makers and practitioners.

The chances for improved communication between higher education research and higher education policy and practice might be viewed as good: policy and practice actors like to style themselves as strategic and influential, and researchers like to style themselves as those who understand the logics and the movements of higher education. As they both suffer from the complexity of a situation which had been described as "age of supercomplexity" (Barnett 2000) and "age of uncertainty" (Nowotny et al. 2001), readiness for the search of the unknown 'truth' and 'solution' might be higher than in the past.

Open Access This chapter is distributed under the terms of the Creative Commons Attribution Noncommercial License, which permits any noncommercial use, distribution, and reproduction in any medium, provided the original author(s) and source are credited. 


\section{References $^{1}$}

Allen, J., \& van der Velden, R. (Eds.). (2011). The flexible professional in the knowledge society: New challenges for higher education. Dordrecht: Springer.

Altbach, P. G. (1979). Comparative higher education. London: Mansell.

Altbach, P. G. (2002). Research and training in higher education: The state of the art. Higher Education in Europe, 27(2), 153-168.

Altbach, P. G. (2014). Knowledge for contemporary university: Higher education as a field of study and training. In L. E. Rumbley, P. G. Altbach, D. A. Stanfield, Y. Shimmi, A. de Gayardon, \& R. Y. Chan (Eds.), Higher education: A worldwide inventory of research centers, academic programs, and journals and publications (3rd ed.). Bonn: Lemmens Media.

Altbach, P. G., \& Engberg, D. (Eds.). (2000). Higher education: A worldwide inventory of centers and programmes. Chestnut Hill, MA: Boston College, Center for International Higher Education.

Altbach, P. G., Bozeman, L. A., Janashia, N., \& Rumbley, L. A. (Eds.). (2007). Higher education: A worldwide inventory of centers and programmes. Revised Edition. Rotterdam: Sense.

Altbach, P. G., Reisberg, L., \& Rumbley, L. A. (2009). Trends in global higher education: Tracking an academic revolution. Paris: UNESCO.

Amaral, A., \& Magalhaes, A. (2013). Higher education research between policy and practice. In B. M. Kehm \& C. Musselin (Eds.), The development of higher education research in Europe: 25 years of CHER (pp. 43-59). Rotterdam, Boston and Taipei: Sense.

Barblan, A. (2011). Epilogue: From the university in Europe to the universities of Europe. In W. Rüegg (Ed.), A history of the university in Europe (Vol. IV, pp. 550-574)., Universities since 1945 Cambridge: Cambridge University Press.

Barnett, R. (2000). Realizing the university in an age of supercomplexity. Buckingham: Open University Press \& SRHE.

Becher, R. A. (1992). Disciplinary perspectives on higher education: Introduction. In B. R. Clark \& G. Neave (Eds.), The encyclopedia of higher education (pp. 1763-1776). Oxford: Pergamon Press.

Begg, R. (Ed.). (2003). The dialogue between higher education research and practice. Dordrecht: Kluwer Academic Publishers.

Brennan, J., \& Teichler, U. (2008). Special issue: The future of higher education and the future of higher education research. Higher Education in Europe, 56(3).

Burrage, M. (Ed.). (2010). Martin trow: Twentieth-century higher education, Baltimore. MD: Johns Hopkins University Press.

CHEPS, INCHER, \& ECOTEC. (2008). ERASMUS and quality, openess and internationalisation in higher education in Europe. Enschede: Twente University, CHEPS.

CHEPS, INCHER, \& ECOTEC. (2010). The first decade of working on the European higher education area: The Bologna process independent assessment (Vol. 1). Enschede: Twente University, CHEPS.

Clark, B. R. (1983). The higher education system: Academic organization in cross-national perspective. Berkeley, CA: University of California Press.

Clark, B. R. (Ed.). (1984). Perspectives on higher education: Eight disciplinary and comparative views. Berkeley, CA: University of California Press.

Clark, B. R., \& Neave, G. (Eds.). (1992). The encyclopedia of higher education. 4 volumes. Oxford: Pergamon Press.

Curaj, A., Scott, P., Vlasceanu, L., \& Wilson, L. (Eds.). (2012). European higher education at the crossroads: Between the Bologna Process and National Reforms (Vol. 2). Dordrecht: Springer.

${ }^{1} \mathrm{Cf}$. also the literature in Table 2 . 
Deca, L. (2012). Preface. In A. Curaij, P. Scott, L. Vlasceanu, \& L. Wilson (Eds.), European higher education at the crossroads: Between the Bologna Process and National Reforms (1 Ed., pp. v-vi). Dordrecht: Springer.

El-Khawas, E. (2000). Research, policy and practice: Assessing their actual and potential linkages. In U. Teichler \& J. Sadlak (Eds.), Higher education research: Its relationship to policy and practice (pp. 37-44). Oxford: Pergamon \& IAU Press.

Eurydice (Ed.). (2010). Focus on higher education in Europe 2010-The impact of the Bologna Process. Brussels: Eurydice.

Forest, J. J., \& Altbach, P. G. (Eds.). (2006). International handbook of higher education. Dordrecht: Springer.

Frackmann, E. (1997). Research on higher education in Western Europe: From policy-advice to self-reflection. In J. Sadlak \& P. G. Altbach (Eds.), Higher education research at the turn of the new century (pp. 107-126). New York: UNESCO, Garland.

Frackmann, E., \& Maassen, P. (Eds.). (1992). Towards excellence in higher education. Utrecht: Lemma.

Fromment, E., Kohler, J., Purser, L., \& Wilson, L. (Eds.). (2006). EUA Bologna handbook: Making Bologna work. Berlin: Raabe Academic Publishers.

Fumasoli, T., Goastellec, G., \& Kehm, B. K. (Eds.). (2015). Academic work and careers in Europe: Trends, challenges, perspectives. Cham: Springer.

Gaebel, M., Purser, L., Wächter, B., \& Wilson, L. (Eds.). (2008). Internationalisation of European higher education: An EUA/ACA handbook. Berlin: Dr. Josef Raabe.

Goldschmidt, D., Teichler, U., \& Webler, W. D. (Eds.). (1984). Forschungsgegenstand Hochschule: Überblick und Trendbericht (Higher education as a theme of research: Overview and trend report). Campus: Frankfurt a.M. and New York.

Gornitzka, A. (2013). The interface between research and policy-A note with potential relevance for higher education. European Journal of Higher Education, 3(3), 255-264.

Gornitzka, A., \& Larsen, M. I. (2004). Towards professionalisation? Restructuring the administrative work force in universities. Higher Education in Europe, 47(4), 455-471.

Gunkel, S., Freidank, G., \& Teichler, U. (Eds.). (2003). Directory der Hochschulforschung: Personen und Institutionen in Deutschland (Directory of Higher Education Research: Persons and institutions in Germany). Hochschulrektorenkonferenz (Beiträge zur Hochschulpolitik): Bonn.

Horta, H., \& Jung, J. (2013). Higher education research in Asia: An archipelago, two continents or merely atomization? Higher Education in Europe, 68(1), 117-134.

Huisman, J., \& van der Wende, M. (Eds.). (2004-2005). On cooperation and competition. Bonn: Lemmens.

Janson, K., Schomburg, H., \& Teichler, U. (2009). The professional value of ERASMUS mobility. Bonn: Lemmens.

Kehm, B. M. (2005). Looking back to look forward: Ten years of TEAM. Tertiary Education and Management, 11(2), 93-110.

Kehm, B. M., \& Musselin, C. (Eds.). (2013). The development of higher education research in Europe: 25 years of CHER. Rotterdam, Boston and Taipei: Sense.

Kehm, B. M., \& Teichler, U. (2007). Research on internationalisation in higher education. Journal of Study in International Education, 11(3-4), 260-273.

Kehm, B. M., \& Teichler, U. (2013a). Organisational strategy and the profile of CHER members. In B. M. Kehm \& C. Musselin (Eds.), The development of higher education research in Europe: 25 years of CHER (pp. 25-33). Rotterdam, Boston and Taipei: Sense.

Kehm, B. M., \& Teichler, U. (Eds.). (2013b). The academic profession in Europe: New tasks and new challenges. Dordrecht: Springer.

Kehm, B. M., Huisman, J., \& Stensaker, B. (Eds.). (2009). The European higher education area: Perspectives on a moving target. Rotterdam and Taipei: Sense.

King, R., Marginson, S., \& Naidoo, R. (Eds.). (2013). The globalization of higher education, Cheltenham and Northhampton. MA: Edward Elgar. 
Klemencic, M. (2014). The future of higher education research in Europe. European Journal of Higher Education, 4(1), 1-5.

Klemencic, M., \& Brennan, J. (2013). Institutional research in a European context: A forward look. European Journal of Higher Education, 3(3), 265-279.

Knowles, A. S. (Ed.). (1977). International encyclopedia of higher education. San Franciso, CA and London: Jossey-Bass.

Kosmützky, A., \& Krücken, G. (2014). Growth or steady state? A bibliometric focus on international comparative higher education research. Higher Education in Europe, 67(4), 457-472.

Kottmann, A., \& Enders, J. (2013). Die neuen Hochschulprofessionellen in Europa: Ausdifferenzierung und Aufgaben im internationalen Vergleich (The new higher education professionals in Europe: Differentiation and tasks in intrnational comparison). In C. Schneijderberg, N. Merkator, U. Teichler, \& B. M. Kehm (Eds.), Verwaltung war gestern? Neue Hochschulprofessionen und die Gestaltung von Studium und Lehre (Was Administration yesterday? New higher education professions and the shaping of learning and teaching) (pp. 305-333). Frankfurt a. M. and New York: Campus.

Kwiek, M. (2013). Knowledge Production in European Universities. Frankfurt a. M. and New York: Peter Lang.

Maassen, P. A. M. (2000). Higher Education Research: The Hourglass Structure and its Implication. In U. Teichler \& J. Sadlak (Eds.), Higher Education Research: Its Relationship to Policy and Practice (pp. 59-67). Oxford: Pergamon \& IAU Press.

Maassen, P. A. M., \& Pausits, A. (2013). Higher Education Management Programmes in Europe: From Grass-roots to Sustainable Development and Impact. In B. M. Kehm \& C. Musselin (Eds.), The Development of Higher Education Research in Europe: 25 Years of CHER (pp. 6986). Rotterdam, Boston and Taipei: Sense.

Macfarlane, B. (2011). The morphing of academic practice: Unbundling and the rise of the para-academic. Higher Education Quarterly, 65(1), 59-73.

Macfarlane, B. (2012). The higher education research archipelago. Higher Education Research and Development, 31(1), 129-131.

Meek, V. L., Teichler, U., \& Kearney, M.-L. (Eds.). (2009). Higher Education, Research, Innovation: Changing Dynamics. Kassel: International Centre for Higher Education Research.

Meek, V. L., Goedegebuure, L., Santiago, R., \& Carvalho, T. (Eds.). (2010). The Changing Dynamics of Higher Education Middle Management. Dordrecht: Springer.

Merkator, N., \& Schneijderberg, C. (2012). Hochschulprofessionen - Thematik und quantitative Bilanz (Higher education professionals - themes and quantitative account). In B. M. Kehm, H. Schomburg, \& U. Teichler (Eds.), Funktionswandel der Universitäten: Differenzierung, Relevanzsteigerung, Internationalisierung (Functional change of universities: Diversification, increasing relevance, internationalisation) (pp. 412-441). Frankfurt a. M. and New York: Campus.

Mora, J.-G., Detmer, A., \& Vieira, M.-J. (2010). Good Practices in University-Enterprise Relationships GOODUEP. Valencia: Valencia University of Technology.

Mora, J.-G., Schomburg, H., \& Teichler, U. (2013). Empleo y trabajo de los graduados universitarios: Conclusiones de diferentes estudios (Employment and work of university gaduates: Results of different studies). Barcelona: Octraedo - ICE.

Neave, G., \& Teichler, U. (1989). Research on higher education in Europe (special issue). European Journal of Education, 24(3).

Nitsch, W., \& Weller, W. (1970-1973). Social Science Research on Higher Education and Universities. The Hague and Paris: Mouton.

Nowotny, H., Scott, P., \& Gibbons, M. (2001). Rethinking Science: Knowledge Production in an Age of Uncertainty. London: Polity Press.

OECD. (2008). Higher Education to 2030 (Vol. 1). Demography, Paris: OECD.

OECD. (2009). Higher Education to 2030 (Vol. 2). Globalisation, Paris: OECD.

Oehler, C., \& Webler, W.-D. (Eds.). (1988). Forschungspotentiale sozialwissenschaftlicher Hochschulforschung: Bundesrepublik Deutschland - Österreich - Schweiz (Research 
Potentials of social science-oriented higher education research: Federal Republic of Germany - Austria - Switzerland). Weinheim: Deutscher Studien Verlag.

Orr, D., Gwosd, C., \& Netz, N. (2011). Social and Economic Conditions of Student Life in Europe. Bielefeld: W. Bertelsmann.

Over, A. (1988). Die deutschsprachige Forschung über Hochschulen in der Bundesrepublik Deutschland: Eine kommentierte Bibliographie (The German-language research on hihger education in the Federal Republic of Germany: A bibliography with comments). München: Saur.

Pasternack, P. (2006). Was ist Hochschulforschung? Eine Erörterung anlässlich der Gründung der Gesellschaft für Hochschulforschung (What is higher education research? A discussion on the occasion of the foundation of the Society for Higher Education Research). Das Hochschulwesen, 54(3), 105-112.

Pasternack, P. (Ed.). (2014). Hochschulforschung von innen und seitwärts: Sichtachsen durch ein Forschungsfeld (Higher education from within and from aside: Perspectives through an research field). Wittenberg: Institut für Hochschulforschung (die hochschule. Journal für wissenschaft und bildung, 1/2014).

Ritter, U. P., \& Kühn, H. P. (1985). Higher Education by the Year 2000. Campus: Frankfurt a. M. and New York.

Roesser, V. J. (2004). A national study on midlevel leaders in higher education: The unsung professionals in the academy. Higher Education, 48(3), 317-337.

Rosselle, D., \& Lentiez, A. (1999). The ERASMUS Programme 1987-1995: A Qualitative Review, Looking to the Future .... Lille: Pôle Universitaire Europeénne.

Rüegg, W. (Ed.). (2011). A History of the University in Europe (Vol. 4). Cambridge: Cambridge University Press.

Rumbley, L. E., Altbach, P. G., Stanfield, D. A., Shimmi, Y., Gayardon, A., \& Chan, R. Y. (Eds.). (2014). Higher Education: A Worldwide Inventory of Research Centers, Academic Programs, and Journals and Publications (3rd ed.). Bonn: Lemmens Media.

Sadlak, J., \& Altbach, P. G. (1997). Higher Education Research at the Turn of the New Century. Paris: UNESCO; New York: Garland.

Sadlak, J., \& Hüfner, K. (2002). International Governmental Organisations and Research on Higher Education. In J. Enders \& O. Fulton (Eds.), Higher Education in a Globalising World (pp. 87-100). Dordrecht: Kluwer Academic Publishers.

Schneijderberg, C., \& Merkator, N. (2012). The New Higher Education Professionals. In B. M. Kehm \& U. Teichler (Eds.), The Academic Profession in Europe: New Tasks and New Challenges (pp. 53-92). Dordrecht: Springer.

Schomburg, H., \& Teichler, U. (2006). Higher Education and Graduate Employment in Europe: Results of Graduate Surveys from Twelve Countries. Dordrecht: Springer.

Schwarz, S., \& Teichler, U. (Eds.). (2000). The Institutional Basis of Higher Education Research. Dordrecht: Kluwer Academic Publishers.

Scott, P. (2000). Higher Education Research in the Light of a Dialogue between Policy-makers and Pracitioners. In Teichler \& J. Sadlak (Eds.), Higher Education Research: Its Relationship to Policy and Practice (pp. 123-148). Oxford: Pergamon \& IAU Press.

Scott, P. (2008) The Internationalisation of Higher Education and Research: Purposes and Drivers. In M. Gaebel, L. Purser, B. Wächter and L. Wilson (Eds.), Internationalisation of European Higher Education: An EUA/ACA Handbook, Berlin: Dr. Josef Raabe, section A.3.1-1.

Shin, J. C., \& Teichler, U. (Eds.). (2014). The Future of the Post-Massified University at the Crossroads: Restructuring Systems and Functions. Dordrecht: Springer.

Steinhardt, I., \& Schneijderberg, C. (2014). Hochschulforschung als Gemischtwarenladen: Karrieremöglichkeiten des wissenschaftlichen Nachwuchses in einem heterogenen Feld (Higher education as a all-sorts-of everything store: Career opportunities of junior academics in a heteregeneous field). In P. Pasternack (Ed.), Hochschulforschung von innen und seitwärts: Sichtachsen durch ein Forschungsfeld (Higher education from within and from aside: Perspectives through an research field) (pp. 63-75). Wittenberg: Institut für Hochschulforschung (die hochschule. Journal für wissenschaft und bildung, 1/2014). 
Sursock, A., \& Smidt, H. (2010). Trends 2010: A Decade of Change in European Higher Education. Brussels: European University Association.

Taylor, J., Hanlon, M., \& Yorke, M. (2013). The evolution and practice of institutional research. New Directions for Institutional Research, 157, 59-75.

Teichler, U. (1980). Review. Proceedings of the National Academy of Education, 7, 55-93.

Teichler, U. (1996). Comparative higher education: Potentials and limits. Higher Education, 32(4), 431-465.

Teichler, U. (2005). Research on higher education in Europe. European Journal of Education, 40 (4), 447-469.

Teichler, U. (Ed.). (2007). Careers of university graduates: Views and experiences in comparative perspectives. Dordrecht: Springer.

Teichler, U. (2010a). Europäisierung der Hochschulpolitik (Europeanization of higher education policy). In D. Simon, A. Knie, \& S. Hornbostel (Eds.), Handbuch Wissenschaftspolitik (Handbook science policy) (pp. 51-70). Wiesbaden: VS Verlag für Sozialwissenschaften.

Teichler, U. (Ed.). (2010b). Internationalising higher education: Debates and changes in Europe (Vol. 263-283). Dordrecht: Springer.

Teichler, U. (2013a). Academically ambitious and relevant higher education research: The legacy of the Consortium of higher education researchers. European Journal of Higher Education, 3 (3), 242-254.

Teichler, U. (2013b). The initial objectives of CHER to form a professional organisation of higher education researchers. In B. M. Kehm \& C. Musselin (Eds.), The development of higher education research in Europe: 25 years of CHER. Sense: Rotterdam, Boston and Taipei.

Teichler, U. (2013c). Yôroppa no kôtô kyôiku kenkyû (Higher education research in Europe). Kôtôkyôikukenkyû (Japanese Journal of Higher Education Research), 16, 123-143.

Teichler, U. (2014a). Higher education research. In International encyclopedia of social and behavioral sciences (2 ed.). Oxford: Elsevier (forthcoming).

Teichler, U. (2014b). Opportunities and problems of comparative higher education research: The daily life of research. Higher Education, 67(4), 393-408.

Teichler, U., \& Gordon, J. (2001). Mobility and cooperation in education-Recent experiences in Europe (special issue). European Journal of Education, 36(4).

Teichler, U., \& Höhle, E. A. (Eds.). (2013). The work situation of the academic profession in Europe: Findings of a survey in twelve countries. Dordrecht: Springer.

Teichler, U., \& Maiworm, F. (1997). The ERASMUS experience: Major findings of the ERASMUS evaluation research project. Luxembourg: Office for Official Publications of the European Communities.

Teichler, U., \& Sadlak, J. (Eds.). (2000). Higher education research: Its relationship to policy and practice. Oxford: Pergamon \& IAU Press.

Teixeira, P. N. (2013). Reflecting about current trends in higher education reseach: A view from the journals. In B. M. Kehm \& C. Musselin (Eds.), The development of higher education research in Europe: 25 years of CHER (pp. 103-121). Rotterdam, Boston and Taipei: Sense.

Tight, M. (2003). Researching higher education. Buckingham: SRHE \& Open University Press.

Tight, M. (2012). Researching higher education (2nd ed.). Maidenhead: Open University Press and McGraw-Hill Education.

Tight, M., Mok, K. H., Huisman, J., \& Morphew, C. (Eds.). (2009). The Routledage international handbook of higher education. New York: Routledge.

Van der Wende, M. \& Huisman, J. (2004). Review of EU policies and research in higher education. Policy Synthesis Paper, Enschede: University of Twente, CHEPS.

Whitchurch, C. (2009). The rise of the blsended professional in higher education: A comparison between the United Kingdom, Australia and the United States. Higher Education, 58(3), 407418.

Winter, M. (2014). Topographie der Hochschulforschung in Deutschland (Topography of higher education research in Germany). In P. Pasternack (Ed.), Hochschulforschung von innen und seitwärts: Sichtachsen durch ein Forschungsfeld (Higher education from within and from 
aside: Perspectives through an research field). (pp. 25-49). Wittenberg: Institut für Hochschulforschung (die hochschule. Journal für wissenschaft und bildung, 1/2014).

Zgaga, P. (2013). Higher education research and higher education policy in South-East Europe. European Journal of Higher Education, 3(3), 280-294.

Zimmermann, K., Kamphans, M., \& Metz-Göckel, S. (Eds.). (2008). Perspektiven der Hochschulforschung (Perspectives of higher education research). Wiesbaden: VS Verlag für Sozialwissenschaften. 